\title{
Jeanne Gaakeer* \\ Interdisciplinarity 3.0: The Hub of the Universe or Fantasy Island?
}

https://doi.org/10.1515/pol-2020-2020

Published online September 21, 2020

\begin{abstract}
This contribution provides, in a condensed form, the argument on the topic of interdisciplinarity within Law and the Humanities of my recent book Judging from Experience. Law, Praxis, Humanities. It also engages with recent proposals for the future, both in Law and Humanities and as far as the humanities in themselves are concerned. Its main point is that any "Law and" field that remains theoretical and does not seek to inform legal practice will suffer from a lack of impact of the kind university administrators demand from academic researchers. If interdisciplinary fields are to thrive, they need to provide nourishment to the legal professional by combining the findings of academic theory (including but not limited to legal doctrine) with the specifics of doing law.
\end{abstract}

Keywords: Ausdifferenzierung, contextualisation, critical reflection, hermeneutics, impact, Law and Humanities

\section{Bridging the Chasm?}

In the good old days of what we cherish as late twentieth-century disciplinary collaborations in law, even though some scholars already worried about negative disciplinary consequences such as the death of law brought about by Law and Economics and Critical Legal Studies or the impossibility of being interdisciplinary, ${ }^{1}$ we only used to fret about terminology. Whether our conjunctions were

1 Owen M. Fiss, “The Death of the Law," Cornell Law Review 72 (1986): 1-16, 14, fearing a negative effect "on public values in larger society" caused by the instrumentalist outlook of these movements; Stanley Fish, “Being Interdisciplinary is So Very Hard To Do," Issues in Integrative Studies 9 (1991): 99-112, 106, that the epistemological argument to reveal hidden power structures with respect to organising knowledge has as a result that "being interdisciplinary [...] is not a possible human achievement. Being interdisciplinary is more than hard to do: it is impossible to do."

*Corresponding author: Jeanne Gaakeer, Erasmus University Rotterdam, Rotterdam, Netherlands, E-mail: gaakeer@law.eur.nl 
transdisciplinary - a mere exchange of findings as noted by Richard Posner in his definition of Law and Economics as "the application of economic theory to legal questions"2 -; multidisciplinary, for lack of clear boundaries as Kuklin and Stempel suggested; ${ }^{3}$ cross-disciplinary and/or cross-cultural, as Stephen Greenblatt's advocacy for the comparative, culturally-tolerant study of literature implied $;{ }^{4}$ or fundamentally interdisciplinary, in the sense denoted by James Boyd White. The latter implies a construction of new meaning that aims at articulating the specificity of our acting with disciplinary languages and value systems, both legal and otherwise, so that the foundations of both disciplines can be understood in their mutual connection, and an inter-discipline can be founded on that basis. ${ }^{5}$

As Law and Literature thrived and developed into Law and the Humanities, however, we extended the already existing dichotomies between the humanities

2 Richard Posner, Law and Literature: a misunderstood relation (Cambridge, MA: Harvard University Press, 1988), 1.

3 Bailey Kuklin and Jeffrey Stempel, Foundations of the Law (St. Paul, MN: West Publishing Co., 1994), 174, “Clear boundaries are hard to find. Although the 'law and' movements are bounded by clouds more than fences, they share a commitment to the idea that law is best studied in a broad and multi-disciplinary fashion."

4 Stephen Greenblatt, “What is the History of Literature?,” Critical Inquiry 23 (1997): 460-481, 472, claiming that the study of literature must not only be "cross-disciplinary [but] also cross-cultural; there is nothing to be gained by staying within one's own national boundaries because a culture's fitness for a particular discursive practice can only be grasped by setting it against another's."

5 See James Boyd White, Justice as Translation. An Essay in Cultural and Legal Criticism (Chicago: Chicago University Press, 1990), 19, that the integrative knowledge that results is not "the transfer of 'findings' from field to field, nor the transportation of 'method' [...] but a bringing to consciousness of the nature of our own intellectual and linguistic practices." See also, more recently, a comparable view voiced by Stuart Henry, "Interdisciplinarity in the Fields of Law, Justice, and Criminology," Chapter 28 in The Oxford Handbook of Interdisciplinarity, 2nd ed., eds. Robert Frodeman, Julie Thompson Klein \& Roberto C. S. Pacheo (Oxford: Oxford University Press, 2017): 397-411, 397, that "law and legal studies illustrate one approach to interdisciplinarity whereby two disciplines join together to form a hybrid, such that concepts, theories, and applications emerge from the nexus of two disciplinary traditions. Examples of this approach [...] law and psychology, law and society, anthropology of law, economics and law, feminism and law, critical legal studies, masculinities and law, and semiotics and law.” Also note that Henry, as late as 2017, does not mention Law and Humanities. For a terminological overview, see the pioneer of interdisciplinarity, Julie Thompson Klein, "Typologies of Interdisciplinarity, The Boundary Work of Definition," Chapter 3 in The Oxford Handbook of Interdisciplinarity, 2nd ed., eds Robert Frodeman, Julie Thompson Klein \& Roberto C. S. Pacheo (Oxford: Oxford University Press, 2017): 21-39. 
and the natural sciences that C. P. Snow had helped survive. ${ }^{6}$ Scepticism set in. Beyond the originally favourable opposition of literary woman to economic man and his fellow creature the authoritarian man of law as a hard, doctrinally positivistic discipline, ${ }^{7}$ issues of inferiority and superiority entered the scene, as did those of colonisation and gender. In short, antagonism and, subsequently, the critique thereof set in as the conceptual clarity and rationality required of law began to be (over) emphasised. Jack Balkin voiced the idea that the discipline connected to law by the ampersand might be an invader, or a coloniser, as happened in the case of Law and Economics, so that interdisciplinary scholarship then ends up as the incomplete or failed take-over of law by another discipline at the most. ${ }^{8}$ Gyora Binder and Robert Weisberg followed suit and spoke in terms of a host and a guest discipline. ${ }^{9}$ Kenji Yoshino pointed to the opposition of law as "a machine made of words," and literature as "marked by qualities stigmatized within the law, such as falsity, irrationality, and seductiveness."10 Greta Olson criticised the gendered terms of soft literature versus hard law. ${ }^{11}$ By then, in 1996, Penelope Pether had already 'jangled the keys of the Kingdom' and Judith Resnik had made suggestions in terms of mapping the field and changing the topic to avoid the risk of sticking to canonical Anglo-American law in/as literature. ${ }^{12}$

Scepticism of another kind was voiced by Jane Baron and Julie Stone Peters. They pointed to the lack of debate on the phenomenon of interdisciplinarity itself: they raised the issue of dichotomous disciplinary boundaries from a different

6 Charles P. Snow, The Two Cultures [1959] (Cambridge: Cambridge University Press, 1993); Stephen J. Gould, The Hedgehog, the Fox, and the Magister's Pox. Mending the gap between science and the humanities (New York: Harmony Books, 2003), 81-82, for the claim that the only reason that we ever developed a model of opposition between science and the humanities is our, "deeply entrenched habit of ordering our categories as oppositional pairs," i.e. "this apparently ineluctable human propensity to dichotomize."

7 See Robin West, "Economic Man and Literary Woman: One Contrast," Mercer Law Review 39 (1988): 867-878.

8 Jack M. Balkin, “Interdisciplinarity as Colonization,” Washington and Lee Law Review 53 (1996): 949-70.

9 Guyora Binder and Robert Weisberg, Literary Criticisms of Law (Princeton: Princeton University Press, 2000), 5.

10 Kenji Yoshino, “The City and the Poet," Yale Law Journal 114 (2005): 1835-1896, 1837. Cf. Wendy N. Duong, "Law is Law and Art is Art and Shall the Two Ever Meet? Law and Literature: the comparative creative processes," Southern California Interdisciplinary Law Journal 15 (2005): 1-43. 11 Greta Olson, "Law is not Turgid and Literature not Soft and Fleshy: Gendering and Heteronormativity in Law and Literature Scholarship,” The Australian Feminist Law Journal 36 (2012): 6586.

12 Penelope Pether, “'Jangling the Keys of the Kingdom'," Australian Feminist Law Journal 7 (1996): 61-78; Judith Resnik, “Changing the Topic,” Australian Feminist Law Journal 7 (1996): 95111. 
angle, namely in relation to the whatness of any specific discipline, and claimed that the risk of interdisciplinary work that starts from the premise that the one discipline has to fill the other discipline's void is that it affirms the very idea of the insularity of, and insurmountable boundaries between disciplines, ${ }^{13}$ rather than that it emphasises similarities and cooperations. In a comparable yet totally opposite vein, Pierre Schlag claimed it is rather the "dedifferentiation" problem that is a major complication in interdisciplinary studies: foundational similarities are taken to their logical extreme, so that "The dedifferentiation problem is that there is nothing to be said about the relations between the two entities because we were never entitled to separate them out in the first place."14

\section{Or Minding the Gap?}

Such scepticism suggests that we will do well at this point in time to (re)consider questions of what the boundaries of any set of cooperating disciplines are, or rather how they have been and are currently being constituted, and whether the ampersand functions as a bridge over the perhaps troubled doctrinal waters around disciplinary islands, or as a dam that precludes new academic insights and societal impact. Put differently and in terms of our "Law ands," the question that has kept many interdisciplinary legal scholars busy these past decades is what is internal and what is external to law. It forces us to think not only about disciplinary boundaries, intuitively presumed or authoritatively drawn, but, more importantly, also about the whatness or quidditas of law itself, precisely because of its connection to the tendency, noted above, to place law and literature in opposition as being hard versus soft.

13 Jane B. Baron, "Law, Literature, and the Problems of Interdisciplinarity,” Yale Law Journal 108 (1999): 1059-1085, 1084, "What is 'inside' law and what is 'outside'? This is an essential question for all 'law and' endeavours, for it is only what law does not already include that needs to be added. The idea of 'law and' almost requires 'law and' scholars generally, and law-and-literature scholars particularly, to treat law as a bounded entity, an independent domain. [...] Thus, the independence of law from other disciplines is what creates the possibility of interdisciplinarity"; Julie Stone Peters, "Law, Literature, and the Vanishing Real: on the future of an interdisciplinary illusion,” PML 120:2 (2005): 442-453, 448, "law and literature might be seen as having symptomatized each discipline's secret interior wound: literature's wounded sense of its insignificance, its inability to achieve some praxis; law's wounded sense of estrangement from a kind of critical humanism that might stand up to the bureaucratic state apparatus, its fear that to do law is always already to be complicit, its alienation from alienation itself."

14 Pierre Schlag, “The Dedifferentiation Problem," Continental Philosophy Review 42 (2009): 3562, 37. 
Obviously, the last word has not yet been said - if that is at all possible, of course - about what legal scholarship is, or should be - black letter/doctrinal or interdisciplinary - and what its task is. This is also to ask after interdisciplinarity's intended audiences, and whether interdisciplinary movements in law are "to influence practice," or "merely [to] circulate [...] ideas within the sealed network of a purely academic discourse," as Richard Posner already and also skeptically noted earlier on. ${ }^{15}$ The warning and a lesson for interdisciplinarians here is that research in which theory is utterly divorced from practice is not likely to have any impact of the kind required by university administrators with their hands on the purse-strings. I use the term theory deliberately loosely here in order to refer to legal scholarship in the sense of the academic study of and research into law generally - including the findings of empirical research when used in a legal surrounding - with no a priori doctrinal strings attached.

Or, as Neil Duxbury's analysis of interdisciplinary legal studies suggests, late twentieth-century US American scholarship, while inspiring as far as a widening of scope is concerned, also contains "an astonishing amount of cross-disciplinary chutzpah."16 This demoralises doctrinally-oriented academic jurists and legal professionals, and is what I would call interdisciplinarity as a fantasy island where anything may happen but not necessarily contribute to serious debate (or impact). There may be something romantic in disciplinary rebellion, ${ }^{17}$ but already in 1992 Brian Leiter warned us to avoid the risk of "intellectual voyeurism," i.e. "superficial and ill-informed treatment of serious ideas," that results from a lack of interest in and mutual understanding of the (philosophical) concepts at work in a discipline. ${ }^{18}$ As Mariana Valverde pointed out more recently, the label "interdisciplinary" has long worked well for distinguishing critical scholars from their doctrinal counterparts, but suffers from a pragmatic deficit. ${ }^{19}$

\section{Liminal Moment}

This leads me to reiterate my point recently made in Judging from Experience. Law, Praxis, Humanities, ${ }^{20}$ namely that the movement from the pre-“disciplinary" unity

15 Richard Posner, “Legal Scholarship Today,” Harvard Law Review 115 (2002): 1314-1326, 1317. 16 Neil Duxbury, “A Century of Legal Studies,” Chapter 42 in The Oxford Handbook of Legal Studies, eds. P. Cane and M. Tushnet (Oxford: Oxford University Press, 2003): 950-974, 957.

17 Cf. Balkin, "Colonization," 957, calling interdisciplinarians: "romantic rebels."

18 Brian Leiter, "Intellectual Voyeurism in Legal Scholarship," Yale Journal of Law \& the Humanities 4 (1992): 79-104, 80.

19 Mariana Valverde, "Between a Rock and a Hard Place: Legal Studies Beyond Both Disciplinarity and Interdisciplinarity,” Critical Analysis of Law 1:1 (2014): 51-62.

20 Jeanne Gaakeer, Judging from Experience. Law, Praxis, Humanities (Edinburgh: Edinburgh University Press, 2019), Chapter 3. 
of knowledge of the heyday of Renaissance humanism to the eighteenth-century differentiation of knowledge and nineteenth-century academic pigeonholes brought about the development of separate disciplinary methodologies. This Ausdifferenzierung resulted in the formation of autonomous disciplines with clearly demarcated boundaries in university faculties. As far as ContinentalEuropean law is concerned this proved fruitful to the development of a positivistic approach, and with it, of the idea that the autarky of the discipline is a precondition for the objectivity of its results, an idea shared by US American legal formalism as advocated by Christopher Langdell. ${ }^{21}$

In the artes liberales throughout Europe, a comparable shift occurred. Letters as sources of knowledge and intellectual pursuits long included philosophical, theological, political and scientific works of non-fiction. By contrast, literature as it is studied today is predominantly the realm of fictional narratives. What is more, it should also be noted that the term Geisteswissenschaften as it developed in the German tradition does not fully coincide with the English concept of the moral sciences or humanities, nor with the French sciences humaines or the American liberal arts. ${ }^{22}$ This easily leads to problems of conceptual translation, or rather, misunderstanding. The same goes for the development of law. The US American

21 Christopher Columbus Langdell, A Selection of Cases on the Law of Contracts (Boston: Little, Brown and Co., 1879). See Richard Posner, "The Decline of Law as an Autonomous Discipline," Harvard Law Review 100 (1987): 761-780; Brian Bix, "Law as an autonomous discipline," Chapter 43 in The Oxford Handbook of Legal Studies, eds. P. Cane and M. Tushnet (Oxford: Oxford University Press, 2003): 975-987, for the view that autonomy in law implies that both legal reasoning and legal decision-making are sufficient to themselves; Hanoch Dagan \& Roy Kreitner, "The Interdisciplinary Party," Critical Analysis of Law 1:1 (2014): 23-31, 24, "critical analysis of law promise a distinctive version of interdisciplinarity that aspires to reconceptualize the engagement among disciplines while at the same time recovering the autonomy of law as a discipline;" Cf. Hanoch Dagan \& Roy Kreitner, “The Character of Legal Theory,” Cornell Law Review 96 (2011): 671691, 671, for the view that the Legal Realists proved that the Langdellian view of law as an autonomous discipline was false, after which the notion of a legal theory was discarded and legal scholars began "borrowing a theoretical discipline from the social sciences or the humanities." 22 See also in the context of contemporary Law and Humanities Costas Douzinas, "A Humanities of Resistance: Fragments for a Legal History of Humanity," in Law and the Humanities. An Introduction, eds. Austin Sarat, Matthew Anderson and Cathrine O. Frank (Cambridge: Cambridge University Press, 2010): 49-72, 49, for the view that in the American discussion the humanities are "either a set of academic subjects that typically consists of Classics, Philosophy, History, and Literature (the disciplinary approach) or an attitude toward teaching and learning that could be extended to all types of subjects (the humanistic approach)." 
concept of "the rule of law," for example, differs from its UK counterpart and the continental idea of democratic societies under the rule of law. ${ }^{23}$

Looked upon in retrospect, the development of interdisciplinary ventures aimed as a counter-reaction to the differentiation of both academic disciplines and social power structures characterising late nineteenth-century societies, is paradoxical in that some of these ventures, Law and Economics and earlier on Sociological Jurisprudence and the Law and Society Movement among them, ${ }^{24}$ bring back together what had before the process of Ausdifferenzierung been part of law to start with, ${ }^{25}$ and disregard communalities of law and the humanities pertinent in the medieval bonds of law and literature and those of legal humanism.

In other words, contemporary contextualisation and interdisciplinarity have a long tradition in law and legal theory that has undeservedly been neglected in contemporary interdisciplinary studies. ${ }^{26}$ This should at least alert us to the danger of new disciplinary tendencies as we continue our interdisciplinary course. For US American legal theory Guido Calabresi as early as 1983 offered the metaphor of the swing of the pendulum, claiming that,

Legal scholarship in the last sixty or so years has alternated between two, and probably only two, major themes. One has been legal process [...]. The other theme has been 'law and (some other discipline)'. The two themes are not mutually exclusive. But one has tended to dominate legal scholarship just when the other has finished a period of dominance and growth. ${ }^{27}$

So, if interdisciplinary collaboration fails to offer something for practitioners, doctrinal tendencies may soon crop up. And if Law and Humanities fail in this way,

23 Bernhard Grossfeldt, "Language, Writing and the Law," European Review 5 (1997): 383-399, 386. "If we try, for example, to translate the German word 'Rechtsstaat' into English 'rule of law' - we hear immediately that the German expression 'Staat' ('state') does not find an equivalent." Cf. Tom Bingham, The Rule of Law (London: Allen Lane, 2010), chapter 2, on the 1948 Universal Declaration of Human Rights as a decisive moment for the rule of law.

24 See Oliver Wendell Holmes jr., "Review of Langdell Casebook," American Law Review 14 (1880): 233-235, 234, for a critique of Langdell's theory of law, speaking, again paradoxically though differently, of law as a branch of anthropology. To Holmes, economics, statistics, and other social sciences were the disciplines of the future of law. See also Max Rümelin, Rechtsgefühl und Rechtsbewusstsein (Tübingen: Mohr-Siebeck, 1925), 75, for the early interdisciplinary point that in order to understand the concept of Rechtssgefühl, i.e. legal consciousness, the findings of the behavioural sciences, sociology, history, and literature should be combined.

25 See Gaakeer, Judging, Chapter 2, for the differentiation of economics, sociology and anthropology from the mother discipline of law.

26 For an extended discussion, see Jeanne Gaakeer, "European Law and Literature: Forever Young. The Nomad Concurs," in Dialogues on Justice: European Perspectives on Law and Humanities, eds. Helle Porsdam and Thomas Elholm (Berlin: De Gruyter, 2012): 44-72.

27 Guido Calabresi, “Thoughts on the Future of Economics in Legal Education,” Journal of Legal Education 33 (1983): 359-364, 364. 
empirically inclined collaborations may soon take precedence. In contemporary European legal theory, for example, interdisciplinary Empirical Legal Studies successfully claims impact of a kind that Law and Humanities so far sorely lacks, namely both academic and professional impact. As a result, Empirical Legal Studies is not only successful but it is also regarded by many scholars as the new doctrine, and that is ironical to say the least because empirical legal studies are traced back to Montesquieu, ${ }^{28}$ whereas it is precisely to Montesquieu that we owe the idea that any cultural context is itself a frame of reference in the sense that it offers a specific configuration of views on law, government, society, the good life and man's place in the whole and it is this aspect of Montesquieu that was forgotten in the nineteenth-century process of disciplinary differentiation.

\section{The In-Between and the Go-Between: Intra- or Predisciplinarity?}

This leads me to the question of whether or not we are at a turning point, or as Robert Ferguson called it, a "liminal moment" 29 with Law and Humanities as obviously one of law's liminal discourses from the very start of contemporary interdisciplinary studies. ${ }^{30}$ I say so because while Law and Humanities has cherished and advocated a diversity of approaches, it has for too long disregarded methodological and epistemological questions that could help further the project of Interdisciplinarity 3.0 while seeking to reconnect academic theory to legal practice. The latter task would be in remembrance of the project that John Wigmore and Benjamin Cardozo initiated in the early twentieth century and that became the impetus for contemporary Law and Humanities in the 1970s. As Law and Humanities gained academic scope and quantity it soon became theory only and lost track with its original aim to provide nourishment to the legal professional and support

28 Rens Bod, Een Wereld vol Patronen, de gechiedenis van kennis (Amsterdam: Prometheus, 2019), 397. Bod references Daniel Ho \& Larry Kramer, “The Empirical Revolution in Law," Stanford Law Review 65 (2013): 1195-1205, and Bart Karsten et al., "Reference Structures of National Constitutions," in Proceedings NAil, 2014: 2nd international workshop on 'Network Analysis in Law', eds R. Winkels \& N. Lettieri (2014): 1-12.

29 Robert A. Ferguson, "Proposals and Performative Utterance in the Nineteenth-Century Novel: The Professional Man's Plight," in Subversion and Sympathy: Gender, Law, and the British Novel, eds. Martha C. Nussbaum and Alison L. LaCroix (Oxford: Oxford University Press, 2013): 274-287, 284, "a transitional or liminal moment where status and identity on both sides are up for grabs." 30 Cf. Daniela Carpi and Jeanne Gaakeer (eds.), Liminal Discourses, subliminal tensions in law and literature (Berlin: De Gruyter, 2013). 
to legal practice, exceptions noted such as James Boyd White whose scholarship always also focuses on law's texts in practice.

I claim that from a methodological point, interdisciplinary work in law necessarily combines such form of theory and practice - the practical knowledge and wisdom in the Aristotelian view that one acquires by actual experience, by doing law. ${ }^{31}$ A characteristic feature of legal methodology in practice, i.e. the perception of the case or legal topic at hand, is the constant movement from facts to legal norms, and back. So, ex facta, ex fabula ius oritur, the law in the sense of the decision or claim about legal meaning in a specific case always arises from the facts, from the story. That is why the facts need a hermeneut. Judging is not the unmediated application of objective legal norms to the facts because the facts are always provided by others and they are always already mediated by numerous professional (and private) perspectival lenses before they arrive in court. Or rather, any human act if it is to be called "a fact" waits for the legal professional's interpretation, whether it is the trial lawyer's, the prosecutor's or the judge's. ${ }^{32}$

Since the rediscovery of the Justinian Code studying law is characterised by a language-oriented, philosophical-hermeneutical perspective. As a consequence, jurists in whatever professional guise they work necessarily combine the theoretical and the practical. That is also why law belongs to the humanities. Jurists constantly study the words of the law and ask: "What does this text mean?" That is why they need the insights from philosophical hermeneutics. That is to say not hermeneutics as a methodology for textual interpretation only, but rather as a philosophical view for a broad mode of inquiry into both the texts of law and into the human actions that the law is invoked to help decide about. That is why we should keep in mind on the one hand, what Peter Brooks calls one of our most productive paths of inquiry in Law and Humanities, i.e. that "the humanities can perhaps teach people to read with a fine and necessary suspicion." 33 The humanities' traditional emphasis on the integrating function of the reading experience, on the other hand, also directs us to interdisciplinarity in theory and

31 The category of the intellectual virtues contains the distinction between épistèmè and phronèsis, by which Aristotle meant theoretical knowledge, aimed at "knowing that," and practical wisdom, aimed at "knowing how" and acting according to the circumstances. Phronèsis is necessary to satisfy fully the demands of legal interpretation, on the premise that in a situation of judging one always has to deal with the particulars of a case, and in a specific situation.

Aristotle, Nicomachean Ethics, trans. H. Rackham and ed. J. Henderson (Cambridge, MA, and London: Harvard University Press, 2003), II.ii.3-5, 1104a4-10.

32 See Paul Ricoeur, From Text to Action: Essays in Hermeneutics, II trans. K. Blamey and J. B. Thompson (Evanston, IL: Northwestern University Press, 1991): 155ff.

33 Peter Brooks, “Literature as Law's Other," Yale Journal of Law \& the Humanities 22: 2 (2010): 349-367, 350. 
practice as proposed here. In short, the humanistic study of law should ideally be a praxis, i.e. the merger of reflection with action precisely because jurists are trained for the purpose of doing law. On this view we should look for fundamental commonalities of law, language and literature broadly conceived, because the situation, both in theory and practice, is always a hermeneutical-rhetorical situation.

The flipside is that jurists in interdisciplinary surroundings should avoid what James Boyd White calls disciplinary imperialism, prioritising the language, principles and values of the one cooperating discipline at the expense of the other. ${ }^{34} \mathrm{I}$ very much agree, therefore, with Robert Frodeman who highlights another aspect of the rhetorical situation when he claims that

interdisciplinarity consists not only of the study of how to integrate various accounts of disciplinary knowledge - call this the epistemic task - but just as much the analysis of the challenges surrounding effective communication to different audiences - call this the political or rhetorical element. While exceptions abound, the latter has been neglected within accounts of interdisciplinarity. ${ }^{35}$

This is another way of addressing the issue of the impact required today of academic research. Frodeman also points out that "the incentives and disincentives of academic culture have led interdisciplinarians [...] away from philosophical rhetoric." ${ }^{36}$ He urges us to preserve our "status as thinkers of the "inbetween'."37 And although in 2006 Balkin and Levinson still reiterated the argument that the humanities could provide law with "external sources of knowledge," their observation that "law will always maintain a genuine if uneasy relationship with the humanities as long as it remains a thoroughly rhetorical enterprise," 38 remains salient when understood in Frodeman's terms. I would suggest that it is precisely because of the bond of theory and practice sketched in this paragraph that Law and Humanities' approaches to interdisciplinarity can gain impact by focusing on its stakeholders, i.e. legal professionals looking not only for merely theoretical nourishment but more

34 James Boyd White, "Establishing Relations between Law and Other Forms of Thought and Language,” Erasmus Law Review 1:3 (2008), available at: http://www.erasmuslawreview.nl/ (last accessed 28 October 2019).

35 Robert Frodeman, "The Future of Interdisciplinarity," Chapter 1 in The Oxford Handbook of Interdisciplinarity, 2nd ed., eds Robert Frodeman, Julie Thompson Klein \& Roberto C. S. Pacheo (Oxford: Oxford University Press, 2017): 3-8, 4.

36 Frodeman, "Future," 4.

37 Frodeman, "Future," 5, "interdisciplinarians have a tendency to abandon their status as thinkers of the 'in-between' and join the ranks of the specialists.”

38 Jack M. Balkin and Sanford Levinson, "Law and the Humanities, an uneasy relationship," Yale Journal of Law and the Humanities 18 (2006): 155-186, 186 (italics mine). 
specifically for theory that informs and propels practice. ${ }^{39}$ That is also why any "theoretical interdisciplinarity" should be taken as a form of cooperation that encompasses what academic theory can teach us as far as critical reflection is concerned. ${ }^{40}$

The need for critical reflection is also brought to the fore in contemporary legal theory. In 2011 Paul Stancil provocatively proposed a methodological seating chart at the academic legal dinner party with philosophy at the head of the table because of the precedence of the normative in law and legal studies. ${ }^{41}$ While in his 2012 "minifesto" for the online journal Critical Analysis of Law Markus Dubber has the internal-external dichotomy of interdisciplinary collaborations return with a vengeance, ${ }^{42}$ his definition of “'Internal contextuality': an intradisciplinarity that opens up critical space by regarding law from a particular perspective within the discipline (e.g. historical analysis of law, comparative analysis of law, etc.)" 43 is congenial to me in that it too seeks for something that has always been part and parcel of law, as is my argument about the relation between law and hermeneutics. But it should also at once be noted that legal history, legal philosophy and legal sociology are by now no longer considered as interdisciplinary in terms of the "Law ands," but rather as independent subfields of law (which is precisely the problem in terms of new interdisciplinary cooperations). So when according to Dubber we should view "Critical analysis of law as a contextual model of legal studies [... as] both disciplinary and interdisciplinary, internal and external, domestic and global, doctrinal and theoretical, descriptive and normative," 44 I would agree, not least because of the one other fundamental characteristics of law and hence of the study of law that is

39 See Henry, "Law, Justice, and Criminology," 409, for the suggestion that what he defines as trans-disciplinarity - the definitional point returns once again - that it includes "stakeholders in the public and private domains" by crossing both disciplinary boundaries and sectors of society. 40 As defined by Klein, “Typologies,” 25, “Theoretical ID (i.e. Klein's abbreviation for interdisciplinarity) connotes a more comprehensive general view and epistemological form embodied in creating conceptual frameworks for analysing particular problems, integrating propositions across disciplines, and synthesizing continuities between models and analogies."

41 Paul J. Stancil, "The Legal Academy as Dinner Party: a (short) manifesto on the necessity of inter-interdisciplinary legal scholarship,” University of Illinois Law Review 5 (2011): 1577-1591.

42 Markus D. Dubber, "Critical Analysis of Law: Interdisciplinarity, Contextuality, and the Future of Legal Studies” available at: https://cal.library.utoronto.ca/public/journals/99/CAL.pdf, (last accessed 28 October 2019): 1-4, 1, "External contextuality is true interdisciplinarity in the bilateral sense: the interaction between two disciplines (e.g. philosophy and law rather than the use of one discipline as an opportunity for application of another) (e.g. law as applied philosophy, economics, etc.)."

43 Dubber, "Critical Analysis," 1, italics mine.

44 Dubber, "Critical Analysis,” 3. 
highlighted by Dubber: law's actual normativity, ${ }^{45}$ because that suggests that such contextual model would include addressing questions of how law deeply affects people's lives.

Put differently, it is precisely law's normativity that occasions hermeneutics and rhetoric to be the other indispensable parts of law because as Robert Cover noted very early on, "Legal interpretation takes place in a field of pain and death [...] judge articulates her understanding of a text, and as a result, somebody loses his freedom, his property, his children, even his life," and as a result "pain and death destroy the world that 'interpretation' calls up," ${ }^{46}$ the world defined here as the social construction of an interpersonal reality through language. In other words, the performative aspect of a judge's word, or rather its "homicidal potential," ${ }^{47}$ by means of which legal interpretation is translated into action is the heart of the matter, with as a case in point as far as literature is concerned Franz Kafka's "In the Penal Colony” as an island of terror and torture. The humanities can help the legal professional understand that a division between word and action artificially conceals the violent side of law's practice. To Cover, therefore, a judge's interpretation, bound as it is to practical application, is indissolubly bound to the actions in which it results, and to the effects on people's lives. Dagan and Kreitner thus quite rightly point to the risk of any onesided interdisciplinary attention if this fails to address the question of normativity, i.e. any interdisciplinary analysis of law is or should be "informed by or embedded in a particular theoretical approach to the relationship between law's coerciveness and its normativity."48

The above can be fruitfully connected to the formation of accepted knowledge in law precisely because this is connected to the articulation of the tension between text and context, logic and experience, premise and result as can also be seen in the development of interdisciplinary legal studies itself when viewed as the development of law from the originally exclusive domain of the jurist who analyses and systematises what is to be called knowledge in the field to a broad humanistic concept of law. To put interdisciplinary research in an even wider context, it should be noted that the contextualisation of knowledge (and science

45 Dubber, "Critical Analysis," 3, "Legal studies are not only a social science or a Geisteswissenschaft, but also a normative enterprise." See also Jan M. Smits, "Law and Interdisciplinarity: On the Inevitable Normativity of Legal Studies," Critical Analysis of Law 1:1 (2014): $75-86,76$ and 83 , for the view that one of the causes of the crisis currently felt in legal studies is "the growing separation of the study of positive law and legal philosophy and theory," while it is precisely "Other disciplines [that] can help clarify the different positions on what law ought to be." 46 Robert Cover, "Violence and the Word," Yale Law Journal 95 (1986): 1601-1629, 1601 and 1602. 47 Cover, "Violence,” 1610.

48 Dagan \& Kreitner, “Interdisciplinary Party,” 27. 
for that matter) is itself part of a larger movement that is considered by Stephen Toulmin to be a post-modern return from the theoretical ratio to the practical ratio. Toulmin specifies this development as a return from writing to speaking (from logic to rhetoric), from the general to the specific (from principles to individual cases), and from the universal to the local and the temporary (forms of life and traditions). ${ }^{49}$

Given the history of ideas of law and jurisprudence, an interdisciplinary archaeology is called for as far as I am concerned in order to unearth and retrieve what was always there but undeservedly forgotten and in order to reconnect it to current problems in academia and legal practice. Mariana Valverde suggests that law is perhaps best looked upon as pre-disciplinary in that it is "a more ancient and intellectually heterogeneous enterprise" because from its very start law always was "a professional craft," 50 a view that the Legal Realists in the early twentieth century emphasised. ${ }^{51}$ To view law as a craft in interdisciplinary surroundings has the advantageous connection of theory and practice that I advocate, and it can fulfill its critical function. ${ }^{52}$ This is also to suggest that Toulmin's new philosophy of the return to the practical ratio transcends modernism as it were, in returning to the Aristotelian tradition of the intellectual and moral virtues, e.g. to phronèsis as noted above. Thus, it would perhaps be more accurate here to speak in terms of recontextualisation, when we recall the emphasis on context in the determination of meaning that was characteristic of Renaissance humanism. Disciplines like law that emphasise practical wisdom focus their attention on the particularity of a specific situation, and on intersubjectivity as the basis for debate, argumentation,

49 Stephen Toulmin, Cosmopolis, The Hidden Agenda of Modernity (New York: The Free Press, 1990), 186-190.

50 Valverde, "Between a Rock and a Hard Place," 53-54. Valverde also references Shai Lavi, "Turning the Tables on "Law and ...: a jurisprudential inquiry into contemporary legal theory," Cornell Law Review 96 (2011): 811-838, 812 with its claim that the point in interdisciplinary legal studies is not to subordinate law to the logic of other disciplines but to "bring the logic of other disciplines under the critical scrutiny of jurisprudence."

51 See Kuklin and Stempel, Foundations of the Law, 174 for the view that "law and" movements are not radical jurisprudential shifts but rather "specific restricted areas of interest related to law in which Legal Realist precepts are brought to bear.”

52 See Dagan \& Kreitner, "Character of Legal Theory," for a topology of discourses about law, 673ff, one of them being "law as craft" that took its leave from pure abstract "theory" as did the legal realists. They also argue that "As with many human practices, deep understanding of the evolution and dynamics of law requires some inside information that only law as craft can provide," 685 . 
and deliberation on a plurality of viewpoints and contextualities which the humanities can help elucidate and inform.

\section{The Hub of the Universe: nemo jurista nisi interdisciplinista!}

Now that we have come a long way since the days when scholars of the studia humanitatis gained the epithet "umanista," 53 it is time to ask which direction(s) Law and Humanities in the sense of Interdisciplinarity 3.0 could take. Anker and Meyer have recently made some suggestions. Their "re-imagination" 54 of the field includes attention to globalisation and a call for comparative studies, and "deterritorialization," 55 a call that is most congenial to me not least, as vanity forces me to add, because Greta Olson and I made it on earlier occasions, ${ }^{56}$ but also because of both the rapprochement of common law and civil law and their

53 Julie Thompson Klein and Robert Frodeman, "Interdisciplining Humanities, A Historical Overview," in The Oxford Handbook of Interdisciplinarity, 2nd ed., eds Robert Frodeman, Julie Thompson Klein \& Roberto C. S. Pacheo (Oxford: Oxford University Press, 2017): 144-156, 145, noting also that "the humanities were last to assume modern disciplinary forms." Cf. Harald Höffding's definition: "Humanism denotes, then, not only a literary tendency, a school of philologists, but also a tendency of life, characterized by interest for the human, both as a subject of observation and as the foundation of action," as cited in Tom Rockmore, Heidegger and French Philosophy: humanism, antihumanism and being (London: Routledge, 1995), 61 (Endnote omitted). 54 Elizabeth S. Anker and Bernadette Meyler, "Introduction," in New Directions in Law and Literature, eds. Elizabeth S. Anker and Bernadette Meyler (Oxford: Oxford University Press, 2017): 1-30, 14 "Re-imagining Law and Literature."

55 Elizabeth S. Anker, "Globalizing Law and Literature," in New Directions in Law and Literature, eds. Elizabeth S. Anker and Bernadette Meyler (Oxford: Oxford University Press, 2017): 210-225, 210.

56 Greta Olson, "De-Americanizing Law and Literature Narratives: Opening Up the Story," Law \& Literature 22 (2010): 338-364; Gaakeer, "European Law and Literature”; Greta Olson, "Futures of Law and Literature, A preliminary Overview from a Culturalist Perspective," in Recht und Literatur im Zwischenraum/Law and Literature In-Between, aktuelle inter-und transdisciplinäre Zugänge/ contemporary inter- and transdisciplinary approaches, eds. Christian Hiebaum, Susanne Knaller, Doris Pichler (Bielefeld: Transcript Verlag, 2015): 37-69; Jeanne Gaakeer, "Futures of Law and Literature: a Jurist's Perspective," in Recht und Literatur im Zwischenraum/Law and Literature InBetween, aktuelle inter-und transdisciplinäre Zugänge/contemporary inter-and transdisciplinary approaches, eds Christian Hiebaum, Susanne Knaller, Doris Pichler (Bielefeld: Transcript Verlag, 2015):71-103. 
communalities in various fields of law that have long gone unduly unnoted, to the detriment of interdisciplinary studies. In addition, Greta Olson and I offer a plea for "for conjoined narratological and metaphorical investigations of the legal," for attention to emotion and affect, and for local knowledge. ${ }^{57}$

My plea for attention to the needs of legal practice leads me to combine narratology with the philosophical hermeneutics of Paul Ricoeur and others, also as a way out of any stalemate that we may end up in if we follow the sceptics who point to the risk of embarking upon a methodologically dangerous liaison of dissimilar disciplines. That is to say, whatever liaison there is, law is always normative in a way that other disciplines are not. It is, I would also argue, precisely because in both law and literature our active participation is required in the interpretation of both text and human action that attention to philosophical hermeneutics is called for. John Caputo put it succinctly, "interpretation is not something we do. Interpretation is what we are," so that hermeneutic creativity is about dealing with possibilities, ${ }^{58}$ or what in law would also be called probabilities. So the interdisciplinary study of meaning(s) remains called for, at the micro level of the case at hand and the macro level of law's constitutive narratives. ${ }^{59}$

What is more, because of legal practice's focus on the particular case, law's knowledge is a form of idiographic knowledge or knowledge of the singular. ${ }^{60}$ It is because legal knowledge is not a pre-existing truth, i.e. it is always a form of applied understanding, in that it brings together rules that are not self-applying,

57 Dieter Axt, "Interview with Greta Olson: Feel empowered to tell your own cultural-legal story," Anamorphosis 5:1 (2019): 317-328, 321, "I would continue to encourage European Law and Literature practitioners to concentrate on contextualizing and historicizing whatever literature is important in their specific local environment. This includess taking popular culture seriously," and, 327, "Digitality has definitely changed how we express ourselves and in what form [...] The affects and social mores of reading are also changing as we read and interact with literature and other media on screen." See also Gaakeer, Judging, chapters 9 and 10: Towards a legal narratology I and II.

58 John D. Caputo, Hermeneutics. Facts and Interpretation in the Age of Information (Penguin: Harmondsworth, 2018), 44. And, 55, "Creativity in hermeneutcs is not creating ex nihilo but retrieving." See also Harvey J. Graff, Undisciplining Knowledge - Interdisciplinarity in the Twentieth Century, (Baltimore: Johns Hopkins University Press, 2015).

59 John V. Pickstone, Ways of knowing, a new history of science, technology and medicine, (Manchester: Manchester University Press, 2000), xi, that one of the ways of knowing is "world-readings (or hermeneutics)," and, 4, "the study of meanings", i.e. "of all the worlds we know, whether through everyday life or 'science'."

60 Cf. Wolfgang Krohn, "Interdisciplinary Cases and Disciplinary Knowledge, Epistemic Challenges of Interdisciplinary Research," Chapter 4 in The Oxford Handbook of Interdisciplinarity, 2nd ed., eds. Robert Frodeman, Julie Thompson Klein \& Roberto C. S. Pacheo (Oxford: Oxford University Press, 2017): 40-52, 42 referencing Windelband who, in the hermeneutic tradition of Dilthey, attached equal value to scientific nomothethic knowledge and idiographic knowledge. 
and contexts that differ from case to case, that interpretation and deliberation cannot thrive without practical wisdom. I would therefore answer Valverde's question "how will the ever-present tension between law as a profession and law as a field of scholarly study interact with and shape the project of post-disciplinarity?"61 by advocating the disciplinary bond of law and the humanities in hermeneutics and returning also to what Valverde calls "intellectual habits that are part of law (e.g. argument by analogy) that have long been left behind in scientific reasoning." 62 These include attention to rhetoric viewed as performative language, ${ }^{63}$ also in terms of constituting what are to be called the facts in legal surroundings. ${ }^{64}$ Inasmuch as this calls for historicising law and the humanities research, ${ }^{65}$ it fits in with the trend in the humanities per se to investigate patterns and cycles in order to unearth long-existing similarities. ${ }^{66}$ In short, here is the hub of the interdisciplinary universe in Law and Humanities studies.

What matters therefore deeply when doing interdisciplinary work is to be able to think in- and outside the box of both disciplines at the same time, lest we suffer the slings and arrows of outrageous interdisciplinary fantasy islands. That is to say, we need to be able to combine the internal perspectives and the external perspectives on both disciplinary academic fields of knowledge as well on the practices in and of both fields. This requires an inquiry into the societal conditions in which the normative system of law functions and an inquiry into law's history of ideas of legal concepts because both are influenced by the epistemological characteristics of an era. Rens Bod has recently suggested that the humanities could be looked upon as "overarching field." ${ }^{17}$ I am not sure, however, that we need to subscribe to the new trend Bod also points to, i.e. that "the

61 Valverde, "Between a Rock and Hard Place," 53.

62 Valverde, "Between a Rock and Hard Place," 60. To me, the metaphorical formation of legal concepts (e.g. the man on the Clapham omnibus, the neighbour principle) is another example of how the imaginative and the cognitive are interconnected in law.

63 Simon Stern, "Literary Analysis of Law: Reorienting the Connections Between Law and Literature," Critical Analysis of Law 5:2 (2018):1-8, 1.

64 See Gaakeer, Judging, chapter 10.

65 Stern, "Literary Analysis," 3, "legal scholarship might have other ambitions, such as [...] understanding the circumstances that have made it [i.e. law] what it is - and treating those enabling conditions, rather than a proposed alteration that might flow from them, as the object of analysis.”

66 Rens Bod, A New History of the Humanities: The Search for Principles and Patterns from Antiquity to the Present, trans. Lynn Richards (Oxford: Oxford University Press, 2013), 1, "What are the humanities? [...] Since the nineteenth century the humanities have generally been defined as the disciplines that investigate the expressions of the human mind." (Footnote omitted italics in the original).

67 Bod, New History, 385 (italics in the original). 
integration of supra-disciplinary methods from the humanities, science and social studies has produced new disciplines (for example cultural studies and media studies)."68

While the theoretical value of these new interdisciplines is indisputably not to be underestimated, my caveat would be that such ambition may again divert us from the law in Law and Humanities and eventually result in pure theory only, or rather, in a new academic ghetto. Furthermore, I am not unaware of the influx of modern technologies in law and neither of the fact that, for example, digital technologies may enhance our research in law and the humanities when it comes to the range and speed of textual analyses; I am also aware that computational and corpus linguistics, to name but a few, can be of great value when analysing judicial decisions, especially those of supra- and international courts. But that does not exhaust the question behind our research in theory and practice alike: "What does this text mean?."69

To continue to strive after the right and just answer to it we need to be able to unify the cognitive and creative capacities of the human mind, to connect reflective thought to contextual understanding, and, last but not least, to the legal and literary imagination. All of this should be conceived in the tradition of a broad view of knowledge - jurists have known for a long time that no discipline is an island - or what Giambattista Vico already in 1732 coined as "cultural knowledge as a whole," one that he urged us to acquire in order to stem the then rising tide of disciplinary differentiation. ${ }^{70}$ In short, nemo jurista nisi interdisciplinista!

\section{Bionote}

\section{Jeanne Gaakeer}

Jeanne Gaakeer holds degrees in English Literature (1980), Law (1990) and Philosophy (1992 cum laude). She wrote her dissertation (1995) on the history and development of Law and Literature, and the works of James Boyd White. She currently serves as a senior justice in the criminal law section of the Court of Appeal of The Hague, the Netherlands. She is also professor of

68 Bod, New History, 362.

69 See also N. Katherine Hayles, How We Think, Digital Media and Contemporary Technogenesis (Chicago: University of Chicago Press, 2012).

70 Giambattista Vico, On the Heroic Mind (oration held 20 October 1732), in Vico and Contemporary Thought, eds. Giorgio Tagliacozzo, Michael Moore and Donald Phillip Verene (London: MacMillan Press, 1980), 244. See also Rümelin, Rechtsgefühl, 20, focusing on the legal professional's development of knowledge by means of experience, "the totality of the representations of (the) law present in a person's consciousness, either on the basis of education or accumulated in the mind on the basis of one's own experiences, in other words [...] the sum total of all experience as a unity" [My translation]. 
Jurisprudence: Hermeneutical and Narrative Foundations at Erasmus School of Law, Erasmus University Rotterdam, the Netherlands. Her areas of research include: jurisprudence; legal theory; legal methodology; legal philosophy; Law and Humanities. The current focus of her research is on the development of a legal narratology applicable in European jurisdictions. Among her recent publications are: Judging from Experience. Law, Praxis, Humanities (Edinburgh: Edinburgh University Press, 2019); “Reality, Veracity and Probability in Law and Literature," in Le droit malgré tout, hommage à François Ost, eds Yves Cartuyvels et alia (Brussels: Presses de l' Université SaintLouis, 2018): 559-586; "Fuss about a Footnote, or the Struggle for (the) Law in German legal theory," in As You Law it - Negotiating Shakespeare, eds D. Carpi and F. Ost (Berlin: De Gruyter, 2018): 155-181; J. Gaakeer and others, “Carey Young's Palais de Justice," Law and Humanities 12:2 (2018): 278-310; "Sua Cuique Persona? A Note on the Fiction of Legal Personhood and a Reflection on Interdisciplinary Consequences," Law \& Literature 28:3 (2016): 287-317 